\title{
Author Correction: Nuclei multiplexing with barcoded antibodies for single-nucleus genomics
}

\author{
Jellert T. Gaublomme, Bo Li D, Cristin McCabe, Abigail Knecht, Yiming Yang (D), Eugene Drokhlyansky, \\ Nicholas Van Wittenberghe, Julia Waldman, Danielle Dionne (D, Lan Nguyen, Philip L. De Jager (D, \\ Bertrand Yeung, Xinfang Zhao, Naomi Habib, Orit Rozenblatt-Rosen \& Aviv Regev
}

Correction to: Nature Communications https://doi.org/10.1038/s41467-019-10756-2, published online 02 July 2019.

In the original version of this article, the raw human sequencing data was available at the RADC Resource Sharing Hub through a data use agreement. This data can now be accessed at the Synapse AMP-AD Knowledge Portal [https://www.synapse.org/\#!Synapse: syn22213200]. This has now been corrected in the PDF and HTML versions of the paper. Additionally, Yiming Yang was incorrectly associated with 'Department of Biological Sciences, Columbia University, New York, NY, 10027, USA' and Naomi Habib was incorrectly associated with 'Center for Immunology and Inflammatory Diseases, Division of Rheumatology, Allergy, and Immunology, Massachusetts General Hospital and Harvard Medical School, Boston, MA, 02129, USA' in the HTML version of the paper. The PDF was correct at the time of publication. This has now been corrected in the HTML version of the paper.

Published online: 02 November 2020

\footnotetext{
(c) Open Access This article is licensed under a Creative Commons Attribution 4.0 International License, which permits use, sharing, adaptation, distribution and reproduction in any medium or format, as long as you give appropriate credit to the original author(s) and the source, provide a link to the Creative Commons license, and indicate if changes were made. The images or other third party material in this article are included in the article's Creative Commons license, unless indicated otherwise in a credit line to the material. If material is not included in the article's Creative Commons license and your intended use is not permitted by statutory regulation or exceeds the permitted use, you will need to obtain permission directly from the copyright holder. To view a copy of this license, visit http://creativecommons.org/licenses/by/4.0/.
}

(C) The Author(s) 2020 